\title{
PENGEMBANGAN LEMBAR KEGIATAN PESERTA DIDIK KURIKULUM 2013 BERBASIS KOMPETENSI PESERTA DIDIK KELAS IV SEKOLAH DASAR
}

\author{
Fitriana Devi, Sony Irianto, Sri Muryaningsih \\ Universitas Mahammadiyah Purwokerto, Indonesia \\ fitrianadevi836@gmail.com
}

\begin{abstract}
This research is a Research and Development. Research and development to product in the form of a 21st Century Student Competency Based LKPD Theme 7. The purpose of this research and development include; 1) Generating 2013 Curriculum LKPD Based on 21st Century Student Competency Theme 7 Grade IV Elementary School, 2) Knowing expert validation on the eligibility of 21st Century Student Competency Based LKPD Theme 7 class IV Elementary School, 3) Knowing the teacher's response to Competency Based LKPD Participants 21st Century Students Theme 7 Grade IV Elementary Schools, 4) Knowing students' responses to LKPD Competency Based 21st Century Students Theme 7 Grade IV Primary Schools. The research steps refer to the 4-D model, namely the Defining, Designing, Developing, and Spreading Phase. According to Thiagarajan, Semmel and Semmel. The form of teaching material development is produced in the form of LKPD which has been tested limitedly in grade IV Elementary Schools. The validation results of LKPD that LKPD get the criteria of "very good" (4.43), the results of the teacher's response to the use of LKPD when implementing learning get the criteria of "very good" (4.9), and the results of the students' responses after a limited trial run get the "very good" criteria (4.68). The development of LKPD teaching materials for further research included several questions in one theme and using Think Pair Square learning models.

Keywords: Teaching Materials; Student Student Worksheet (LKPD); 21st Century Student Competencies; Think Pair Square Model
\end{abstract}

\footnotetext{
ABSTRAK

Penelitian ini merupakan Research and Development. Penelitian dan pengembangan bertujuan menghasilkan produk berupa sebuah LKPD Berbasis Kompetensi Peserta Didik Abad 21 Tema 7. Tujuan penelitian dan pengembangan ini antara lain; 1) Menghasilkan LKPD Kurikulum 2013 Berbasis Kompetensi Peserta Didik Abad 21 Tema 7 kelas IV Sekolah Dasar, 2) Mengetahui validasi pakar terhadap kelayakan LKPD Berbasis Kompetensi Peserta Didik Abad 21 Tema 7 kelas IV Sekolah Dasar, 3) Mengetahui respon guru terhadap LKPD Berbasis Kompetensi Peserta Didik Abad 21 Tema 7 kelas IV Sekolah Dasar, 4) Mengetahui respon peserta didik terhadap LKPD Berbasis Kompetensi Peserta Didik Abad 21 Tema 7 kelas IV Sekolah Dasar. Langkah-langkah penelitian mengacu pada model 4-D yaitu Tahap Pendefinisian, Perancangan, Pengembangan, Penyebaran. Menurut Thiagarajan, Semmel dan Semmel. Bentuk pengembangan bahan ajar yaitu dihasilkan berupa LKPD yang telah diuji cobakan secara terbatas pada kelas IV Sekolah Dasar. Hasil validasi LKPD bahwa LKPD mendapatkan kriteria "sangat baik" $(4,43)$, hasil respon guru terhadap penggunaan LKPD pada saat melaksanakan pembelajaran mendapatkan kriteria "sangat baik" $(4,9)$, dan hasil respon peserta didik setelah dilaksanakan uji coba secara terbatas mendapatkan kriteria "sangat baik" (4,68). Pengembangan bahan ajar LKPD untuk penelitian selanjutnya mencakup beberapa soal dalam satu tema dan menggunakan model pembelajaran Think Pair Square.

Kata Kunci : Bahan Ajar; Lembar Kerja Peserta Didik (LKPD); Kompetensi Peserta Didik Abad 21; Model Think Pair Square
}

\begin{tabular}{l|l|l} 
Submitted Mar 18, 2020 & Revised Apr 22, 2020 & Accepted Apr 27, 2020
\end{tabular} 


\section{Pendahuluan}

Pendidikan merupakan upaya untuk meningkatkan kualitas sumber daya manusia. Pendidikan sangat berpengaruh bagi sumber daya manusia, selalu mengalami perubahan, perkembangan dan perbaikan sesuai dengan perkembangan di segala bidang kehidupan. Perubahan dan perbaikan dalam bidang pendidikan meliputi berbagai komponen yang terlibat di dalamnya. Komponen tersebut meliputi kualitas pendidik, mutu pendidikan, perangkat kurikulum, sarana dan prasarana pendidikan dan mutu manajemen pendidikan termasuk di dalamnya menggunakan metode dan strategi pembelajaran yang inovatif. Upaya perubahan dan perbaikan tersebut bertujuan untuk meningkatkan kualitas pendidikan di Indonesia lebih baik.

Kurikulum merupakan suatu program terencana yang terdapat perubahan dan perbaikan di dalam pendidikan. Permendikbud No. 67 (2013: 4) tentang kerangka dasar dan struktur kurikulum SD/MI disebutkan bahwa kurikulum baru ini bertujuan untuk mempersiapkan manusia Indonesia agar memiliki kemampuan hidup sebagai pribadi dan warga negara yang beriman, produktif, kreatif, inovatif, dan efektif serta mampu berkontribusi pada kehidupan bermasyarakat, berbangsa, bernegara, dan peradaban dunia. Kurikulum menurut Dakir (2010: 3) menyatakan Kurikulum ialah suatu program pendidikan berbagai bahan ajar dan pengalaman belajar yang diprogramkan, direncanakan dan dirancangkan secara sistemik atas dasar norma-norma yang berlaku yang dijadikan pedoman dalam proses pembelajaran bagi tenaga kependidikan dan peserta didik untuk mencapai tujuan pendidikan. Kurikulum 2013 berupaya untuk melaksanakan proses pendidikan sesuai dengan definisi pendidikan yang tercantum. Kurikulum 2013 merupakan sebuah kurikulum yang mengutamakan pemahaman skill dan pendidikan berkarakter, peserta didik dituntut untuk memahami materi, aktif dalam berdiskusi dan presentasi serta memiliki sopan santun disiplin yang tinggi. Pendidikan karakter yang akan ditanamkan kepada peserta didik dapat dilakukan pada setiap pembelajaran, khususnya pada mata pelajaran tematik. Pembelajaran tematik merupakan pembelajaran terpadu yang menekankan keterlibatan peserta didik dalam pembelajaran. Peserta didik aktif terlibat dalam pembelajaran dan pemberdayaan dalam memecahkan masalah, sehingga hal ini menumbuhkan kreativitas sesuai dengan potensi dan kecenderungan mereka yang berbeda dengan yang lainnya. Agar peserta didik menjadi tertarik dan mudah untuk memahami pelajaran tematik diperlukan bahan ajar yang sesuai dengan materi yang akan disampaikan oleh guru.

Bahan ajar merupakan segala bahan (baik informasi, alat, maupun teks) yang disusun secara sistematis, yang menampilkan sosok utuh dari kompetensi yang akan dikuasai peserta didik dan digunakan dalam proses pembelajaran dengan tujuan untuk perencanaan dan penelaahan implementasi pembelajaran (Prastowo, 2015: 17). Bahan ajar yang digunakan sangat banyak, salah satunya Lembar Kegiatan Peserta Didik (LKPD). LKPD digunakan untuk mempermudah guru dalam proses belajar mengajar. LKPD berisi panduan yang digunakan untuk melakukan kegiatan pembelajaran. LKPD bagi peserta didik dapat digunakan untuk sumber belajar mandiri tanpa arahan dari guru. Guru hanya sebagai fasilitator dalam proses pembelajaran.

Pengembangan lembar kerja peserta didik (LKPD) dengan menggunakan suatu model pembelajaran yang tepat merupakan pilihan bagi guru dalam meminimalisir kekurangan bahan ajar yang telah digunakan guru selama ini. Pemilihan model pembelajaran yang tepat salah satunya yaitu model pembelajaran kolaboratif Think Pair Square. Model pembelajaran 
kolaboratif Think-Pair-Square merupakan model pembelajaran secara berkelompok yang terdiri 4-5 anggota dalam satu kelompok. Kegiatan pembelajaran menggunakan model pembelajaran kolaboratif terciptalah sebuah pembelajaran yang melibatkan peserta didik dalam menyelesaikan permasalahan yang terdapat pada aktivitas pembelajaran yang harus diselesaikan. Aktivitas pembelajaran tersebut berbasis kompetensi peserta didik abad 21 yang mencerminkan empat hal yaitu Critical Thinking and Problem Solving, Creativity and Innovation, Communication, Collaboration. Proses pembelajaran pada kurikulum 2013 dilaksanakan secara tematik terpadu.

Penelitian yang dikembangkan yaitu "Pengembangan Lembar Kegiatan Peserta Didik (LKPD) Kurikulum 2013 Berbasis Kompetensi Peserta Didik Abad 21 Pada Tema 7 Indahnya Keragaman Di Negeriku kelas IV SD Negeri Kembaran" dalam penelitian ini berbentuk Research \& Development dengan menghasilkan produk berupa LKPD dengan Model Pembelajaran Kolaborasi Think Pair Square yang dimodifikasi menjadi LKPD yang menarik agar peserta didik lebih tertarik dan tidak mudah bosan dalam menyelesaikan aktivitas pembelajaran yang terdapat dalam LKPD tersebut. Pengertian pembelajaran kolaboratif diatas dapat disimpulkan bahwa model pembelajaran kolaboratif adalah sebuah model pembelajaran yang melibatkan peserta didik dengan dibentuk menjadi beberapa kelompok. Tujan model pembelajaran kolaboratif adalah untuk bertukar pikiran, pendapat dan penafsiran sesuai dengan tugas yang diberikan.

Think-Pair-Square dalam Yaqin, M., A, dkk (2018) menyatakan bahwa TPS merupakan saklah satu model pembelajaran yang berpotensi memberdayakan keterampilan kolaboratif terbukti dengan hasil keterampilan peserta didik meningkat sebesar 14\% dari siklus 1 ke siklus 2 , peningkatan keterampilan kolaboratif peserta didik terjadi di setiap indikator. Setiap indikator telah meningkat lebih dari 5\% dan indikator "pemrosesan kelompok" merupakan indikator yang mengalami peningkatan terbesar dari 61\% menjadi 88\%.

Model pembelajaran Think-Pair-Square (TPS) memberikan kesempatan kepada peserta didik untuk bekerja sendiri dan bekerjasama dengan peserta didik lain. Peserta didik dituntut aktif dalam proses pembelajaran berlangsung untuk mencapai sebuah tujuan pembelajaran yang diharapkan. Oleh karena itu, peserta didik tidak boleh menjadi pembelajar yang pasif karena mereka adalah student center dalam proses belajar mengajar.

Penelitian ini juga mengacu pada penelitian-penelitian sebelumnya, yaitu (1) penelitian yang dilakukan oleh Eka Nurjanah dan Muhammad (2017) yang berjudul "Pengembangan LKPD Tematik-Integratif Berbasis Karakter pada Peserta Didik Sekolah Dasar" penelitian ini bertujuan untuk menghasilkan LKPD tematik-integratif yang layak bagi peserta didik dan mengetahui efektifitas LKPD tematik didik yang mengikuti pembelajaran LKPD tematikintegratif dengan peserta didik yang mengikuti pembelajaran -integratif. Hasil yang didapatkan peneliti ini yaitu terlihat peningkatan nilai pada kelas eksperimen lebih besar dari pada kelas kontrol menunjukkan bahwa terdapat perbedaan yang signifikan rerata peningkatan karakter jujur dan peduli peserta didik yang mengikuti pembelajaran menggunakan LKPD tematikintegratif dengan peserta didik yang mengikuti pembelajaran tanpa menggunakan LKPD tematik-integratif, (2) penelitian yang dilakukan oleh Faridhoh Luncana dan Ali (2015) yang berjudul "Pengembangan Lembar Kerja Peserta Didik Tematik-Integratif Berbasis Pendidikan Karakter Pada Peserta Didik Sekolah Dasar" penelitian ini bertujuan untuk mengetahui keefektifan lembar kerja peserta didik tematik-integratif berbasis nilai pendidikan karakter pada peserta didik. Hasil yang didapatkan bahwa LKPD tematik-integratif berbasis pendidikan 
karakter kreatif dan kerja keras yang dikembangkan sangat efektif terhadap pembelajaran di SD. Hasil uji coba menunjukkan perbedaan yang signifikan pada standar hasil belajar peserta didik pada kelas eksperimen dan kelas kontrol. LKPD memberikan pengaruh positif pada peserta didik, (3) penelitian yang dilakukan oleh Ambarita, A (2018) dengan judul "Developing Worksheet Based on Multiple Intelligences to Optimize the Creative Thinking Students". Penelitian ini bertujuan untuk mengembangkan dan mendeskripsikan efektivitas lembar kerja berbasis kecerdasan majemuk untuk mengoptimalkan kemampuan berpikir kreatif peserta didik. Hasil validasi material oleh ahli materi berdasarkan aspek yang dinilai diperoleh nilai 82,85 (kriteria sangat baik), (4) penelitian yang dilakukan oleh Prasinta, D (2018) dengan judul "Development of Inquiry Model Worksheet For 4th Grader Elementary School Students". Penelitian ini bertujuan untuk mengembangkan lembar kerja peserta didik, dan untuk mengetahui efektivitas LKPD berbasis tematis melalui model Inquiry untuk peserta didik kelas empat Sekolah Dasar. Hasil penelitian ini menunjukkan bahwa LKPD yang dikembangkan layak untuk digunakan dan efektif melalui para ahli dari ahli materi dan ahli media dalam meningkatkan hasil belajar peserta didik.

\section{Metode Penelitian}

Penelitian ini menggunakan jenis penelitian Research and Development (R\&D) dengan menggunakan desain penelitian kualitatif dan kuantitatif. Menurut Sugiyono (2016: 297) metode penelitian dan pengembangan atau dalam bahasa inggrisnya Research and Development adalah metode penelitian yang digunakan untuk menghasilkan produk tertentu, dan menguji keefektifan produk tersebut. Untuk dapat menghasilkan produk tertentu digunakan penelitian yang bersifat analisis kebutuhan dan untuk menguji keefektifan produk tersebut supaya dapat berfungsi di masyarakat luas, maka diperlukan penelitian untuk menguji keefektifan produk tersebut. Langkah-langkah penelitian dan pengembangan berpedoman pada model Research and Development 4-D menurut Thiagarajan, Semmel, dan Semmel dalam Trianto (2013:189), yang terdiri dari empat tahap, yaitu: define (pendefinisian), design (desain), develop (pengembangan), disseminate (pendesiminasian atau penyebaran).

Metode pengumpulan data yang digunakan untuk mengumpulkan data dalam penelitian ini adalah tes dan nontes. Sedangkan instrumen penelitian yang digunakan untuk mendapatkan data yaitu: tes, lembar instrumen validasi ahli, lembar instrumen respon guru, lembar instrumen respon peserta didik.

\section{Hasil dan Pembahasan}

Penelitian dan pengembangan yang telah dilakukan ini kemudian menghasilkan lembar kegiatan peserta didik (LKPD) pada mata pelajaran SBdP, IPA, dan Bahasa Indonesia Kurikulum 2013 Berbasis Kompetensi Peserta Didik Abad 21 Pada Tema 7 Subtema 1 Pembelajaran 2 kelas IV SD Negeri Kembaran, pengembangan LKPD telah dinyatakan sangat valid oleh validator ahli. Pengembangan LKPD ini bertujuan untuk memperbaiki LKPD yang digunakan oleh sekolah yang belum menggunakan kompetensi peserta didik abad 21 (Critical Thinking and Problem Solving, Creativity and Innovation, Communication, Collaboration), sehingga dibuatlah LKPD berbasis kompetensi peserta didik abad 21 menggunakan model Think Pair Square yang mengharuskan peserta didik untuk belajar secara kritis. Hasil pengembangan LKPD secara garis besar dalam proses penelitian dan pengembangan yaitu hrus melalui beberapa tahap. Tahap yang dilalui dari model Thiagarajan, Semmel \& Semmel yang terbagi 
dalam 4 tahap yaitu tahap pendefinisian (Define), tahap perancangan (Design), tahap pengembangan (Develop), tahap penyebaran (Disseminate). Tahap tersebut masing-masing menghasilkan data penelitian yang menjadi bagian dari penyusunan produk penelitian dan pengembangan berupa LKPD Berbasis Kompetensi Peserta Didik Abad 21.

Penilaian respon guru dilakukan setelah kegiatan proses pembelajaran selesai. Guru diberikan angket penilaian respon guru tehadap pembelajaran menggunakan bahan ajar LKPD Berbasis Kompetensi Peserta Didik Abad 21 Tema 7 Subtema 1 Pembelajaran 2 kelas IV SD Negeri Kembaran memperoleh rata-rata skor 4,9 dengan kategori "sangat baik". Selain memberikan penilaian guru juga memberikan kritik dan saran yaitu bahan ajar LKPD Berbasis Kompetensi Peserta Didik Abad 21 yang dikembangkan sudah baik, sesuai dengan SK, KD dan Indikator. LKPD dapat membuat peserta didik lebih mudah memahami konsep dan lebih aktif. Peserta didik juga dapat meningkatkan sikap kerjasama antar teman.

Hasil angket respon peserta didik terhadap LKPD Berbasis Kompetensi Peserta Didik Abad 21 diperoleh data rata-rata dari keseluruhan peserta didik yang memilih terhadap penggunaan LKPD Berbasis Kompetensi Peserta Didik Abad 21 dalam proses pembelajaran dengan rata-rata skor 4,68 maka dikategorikan "sangat baik". Dapat disimpulkan bahwa LKPD Berbasis Kompetensi Peserta Didik Abad 21 dapat diterima oleh peserta didik sebagai bahan ajar LKPD Berbasis Kompetensi Peserta Didik Abad 21 yang mampu membantu proses pembelajaran pada tema 7 subtema 1 pembelajaran 2 kelas IV SD Negeri Kembaran.

Penelitian ini sejalan dengan penelitian yang dilakukan oleh Eka Nurjanah dan Muhammad (2017) menyebutkan bahwa LKPD tematik-integratif layak bagi peserta didik dan mengetahui efektifitas atau respon peserta didik dalam penggunaan LKPD tematik-integratif. Hal ini sesuai dengan pernyataan Trianto (2013: 222-223) bahwa LK merupakan panduan peserta didik yang digunakan untuk melakukan kegiatan penyelidikan atau pemecahan masalah. LK memuat sekumpulan kegiatan mendasar yang harus dilakukan oleh peserta didik untuk memaksimalkan pemahaman dalam upaya pembentukan kemampuan dasar. Berrdasarkan penjelasan tersebut maka dapat disimpulkan bahwa LKPD merupakan bagian dari bahan ajar cetak yang menjadi panduan, perlengkapan atau sarana pendukung pelaksanaan rencana pembelajaran.

\section{Simpulan}

Berdasarkan dari hasil analisa data pada BAB IV dengan menggunakan uji coba produk secara terbatas di kelas I V SD Negeri Kembaran maka dapat ditarik kesimpulan sebagai berikut : (1) penelitian ini telah menghasilkan produk final yaitu LKPD Berbasis Kompetensi Peserta Didik Abad 21 Kurikulum 2013 Berbasis Kompetensi Peserta Didik Abad 21 Pada Tema 7 Indahnya Keragaman Di Negeriku kelas IV SD Negeri Kembaran, (2) setelah melaksanakan uji coba terbatas hasil dari angket validator terhadap LKPD mendapatkan kategori sangat baik (3) setelah melaksanakan uji coba terbatas hasil dari angket respon guru terhadap LKPD mendapatkan kriteria sangat baik, (4) setelah melaksanakan uji coba terbatas hasil dari angket respon peserta didik terhadap LKPD mendapatkan kriteria sangat baik.

Berdasarkan pembahasan dan simpulan dari penelitian ini, maka dapat dikemukakan beberapa saran sebagai berikut : (1) bagi kepala sekolah hendaknya memberikan dukungan kepada guru untuk mengembangkan LKPD yang digunakan pada saat pembelajaran dalam 
rangka meningkatkan kreatifitas serta kolaboratif peserta didik pada saat pembelajaran, (2) bagi Guru hendaknya pada saat pembelajaran dapat membuat sendiri LKPD dengan bantuan para validator ahli agar LKPD yang dibuat dapat tersusun dengan baik sesuai materi yang akan di ajarkan, agar guru mempunyai acuan lain untuk belajar yang sebelumnya hanya mengacu pada LKPD yang dimiliki sekolahan, (3) bagi peneliti selanjutnya diharapkan dapat mengembangkan bahan ajar pada materi lain.

\section{Daftar Pustaka}

Ambarita, A. (2018). Developing Worksheet Based on Multiple Intelligences to Optimize the Creative Thinking Students. International Journal of African and Asian Studies, 47, 1-6.

Dakir. (2010). Perencanaan \& Pengembangan Kurikulum. Jakarta. PT Rineka Cipta.

Eka, N dan Muhammad. (2017). Pengembangan LKPD Tematik-Integratif Berbasis Karakter pada Peserta Didik Sekolah Dasar. Jurnal Pendidikan Karakter, 1 (3), 62-68.

Faridhoh, L dan Ali. (2015). Pengembangan Lembar Kerja Peserta Didik Tematik-Integratif Berbasis Karakter pada Peserta Didik Sekolah Dasar. Jurnal Pendidikan Karakter, 1 (5), $76-$ 80 .

Kemendikbud. (2013). Salinan Lampiran Permendikbud No. 67 tahun 2013 tentang kerangka dasar dan struktur kurikulum SD/MI. Jakarta. Kementrian Pendidikan dan Kebudayaan.

Prasinta, D. (2018). Development of Inquiry Model Worksheet For 4th Grader Elementary School Students. Journal IOSR Journal of Research \& Method in Education (IOSR-JRME), 8, $50-57$.

Prastowo, A. (2015). Panduan Kreatif Membuat Bahan Ajar Inovatif. Jogjakarta: Diva Press.

Sugiyono. (2016). Metode Penelitian Kuantitatif, Kualitatif, dan R\&D. Bandung: Alfabeta

Trianto. (2013). Mendesain Model Pembelajaran Inovatif Progresif. Jakarta: Kencana.

Yaqin, M., A, dkk. (2018). Think-Pair-Square Learning: improving student's collaborative skills and cognitive learning outcome on animal diversity course. Jurnal Pendidikan Biologi Indonesia (Indonesia Journal of Biology Education). 4 (2), 135-142 